\title{
Heparin Cofactor 2
}

National Cancer Institute

\section{Source}

National Cancer Institute. Heparin Cofactor 2. NCI Thesaurus. Code C113637.

Heparin cofactor 2 (499 aa, $\sim 57 \mathrm{kDa}$ ) is encoded by the human SERPIND1 gene. This protein plays a role in the glycosaminoglycan-dependent inhibition of thrombin. 